\title{
Mahesh Dattani’s "Do the Needful”: An Unconventional Romantic Comedy
}

\author{
Dr. Pramod Kumar Singh \\ Rajput Inter College \\ Chhapra, Saran, Bihar, India \\ pks13278@gmail.com
}

\begin{abstract}
Mahesh Dattani is a contemporary Indian English Dramatist who gave voice to the 60 million English speakers of India through his drama. He is the first dramatist recognised for his contribution in this field. Through his plays, he raises the problems of eunuch, homosexuality, transgender, child- sexual abuse, gender-discrimination, thought towards HIV-infected people etc. To such issues, he called them 'fringe issue' to whom we face but never take it as a part of society. Through 'Do the Needful' Mahesh Dattani has presented the problems of male homosexuality. The play was broadcasted by BBC. The play 'Do the Needful' is actually an unconventional romantic comedy.

Keywords: Homosexuality, romantic comedy, unconventional, dramatic technique, traditional society, marriage-system, broad-minded etc.

Mahesh Dattani is an Indian dramatist who presents the Indian issues in the English version is very simple and lucid terms. He was born and brought up in Bangalore to Gujarati parents. The business was his family will but drama became his field of interest. After getting perfection as a dancer he chose to be a dramatist but he also acquired the training of an actor, playwright, director, stage-manager with perfection. He is the first Indo-Anglian dramatist who got the Sahitya Academy Award in the field of drama.
\end{abstract}


Do the Needful' is a very beautiful radio play written and presented by Mahesh Dattani. About this play, the New York Times comments:

A playwright of world stature- Mario Relich, Wasafiri in this cleverly constructed radio play, negotiations are underway for an arranged marriage between Alpesh Patel and Lata Gowda. Despite their cultural differences, both the families are desperate for this match. But while all seems genial on the surface, tension simmers beneath the happy facade- for both, Alpesh and Late have their own secrets to hide At last, we have a playwright who gives 60,000,000 English speaking Indians an identity”. (p-1)

Indian English Drama is totally new literary genre in which the great dramatists like Asif Currimbhoy, Mohan Rakesh, Vijay Tendulkar, Girish Karnad and Badal Circar have contributed their best in their own way. Most of these dramatists have presented the theme with Indian contents and style. Among them, Mahesh Dattani is the most prominent writer who thinks and writes in English. Like other dramatists, his theme is not conventional. He always compels his audiences to think over the issues upon which he does his homework. About him, Alque Padamsee says: "At last we have a playwright who gives sixty million English-speaking Indians an identity". 2

Do the Needful" is the best romantic comedy by Mahesh Dattani but it is full of twists. Its theme and plot are Indian but its effect is universal. Indian audiences generally ignore themes like homosexuality. He shows courage and presents it. It is the voice of the marginalised population of India who wants to express their feelings but could not do so. Dattani plotted it. Like various other comedies produce in India its theme moves round the marriage system of India but not in a common way. It deals with the gay-relationship. He mocks at the concept of arrange -marriage system of India and her tradition.

The play 'Do the Needful' is a one-act play and the play moves around the relationship that is being tried to establish between Alpesh Patel and Lata Gowda by their 
family members. On the surface level, it deals with common marriage system of Indian society but as soon as the play moves on, it is found that in the play no one, either Alpesh or Lata wants to marry. In the first statement of Alpesh, the audience finds no complete sentence but a dot, dot, and dot. It is enough to show the feeling of Alpesh. The playwright usages very strong images when he says at the beginning of the play: "I am caught in a traffic jam. why don't you go ahead? I think my carburettor needs a clean-up. (CP-119)

So this beginning tells the next episode of the play very artistically. Alpesh is in the traffic jam. He is under the confusion after hearing the proposal of his marriage and he is not in a position to come out. The other word is also very symbolic when he writes that my carburettor needs a cleanup. We, all, know the importance of carburettor in a vehicle. Without it, a vehicle cannot get started. So it is not easily possible to go ahead. All these opening descriptions tell a lot of about the whole play the play.

Do the Needful" is about marriage. The description shows that both families are wellto-do. They have much open idea. They exchange their view, they present their ideas, they show openness in every field of marriage but it is very unfortunate that they openly do not ask Alpesh and Lata about their feelings. Both-Alpesh and Lata- are educated persons. As soon as Dr. Devraj Gowda, the father, finds the letter of Chandrakant Patel, the father of Alpesh replies to him soon but both parents never talk directly to their own daughter and son. In the play, we also find that parents' care leaves an impression upon children over a long period. Devraj Gowda who has grown up still not thinks as he was treated in his childhood. He has a daughter Lata. He brought her up but still, he cannot understand the feeling of his daughter. He wants to control her as he was controlled by his parents. As he tells:-“

Devraj Gowda:-May be if we were living with my parents, they would have kept an eye on her. (CP: 121) 
In India marriage is the social phenomenon but still, one party tries to impress others. Both Gowda and Patel family are very rich and broad-minded as they think about themselves but still, they have not come out of the common thought of the common people. As the below statement describes:

Devraj Gowda: After all, if they can consider an inter-caste marriage, they must be broad-minded, Like us. (CP-121)

Devraj: He is richer than we are. (CP-121)

Devraj: .......we can take them to the farm. That will impress them. (CP-121-122)

Here families are in search of a trick to influence others but Lata and Alpesh have a different view. Devraj and Prema think that Lata has ruined their life by doing a notorious deed. They think that their daughter should not do such a deed that is harmful to the whole community. They are not ready to get the explanation of Lata what she wants to tell. They are never ready to understand the desire Lata who has established a strong relationship with a Muslim boy. The parents of Lata, without asking the consent of their daughter finalized to marry her to a Gujarati divorced person. Here the drawback comes before the audience when Alpesh and Lata plot plan. Their parents think that these two are ready to marry but the audience understands the whole things. When Alpesh gives a cigarette to Lata and speaks the dialogue of a Hindi movie:

Alpesh: Teri bhi chup, meri bhi chup. (CP-142)

Alpesh: In the movies I am sure.It means 'your silence and mine as well'. (CP-142) 
The two characters get ready to marry but their plan is very curious. Alpesh still carriages on his affairs with Trilok while Lata's affair with Salim is very deep. They meet their respective friends whenever they want but the most interesting fact is that that is no one is worried towards such types of intimate relationships. These two know each other's secret and keep them silently. Their parents are not so much frank in their relationship but these two young people of the new generation are very frank and open with each other.

The elements of modernity can be traced by very well in the play. It is well- known that modernity is nothing but it relies upon the utility of material. The value of a thing is measured in terms of its utility. The more a thing is utilized the more it is preferred by the people. When Gauri, a cow gives birth to a calf, the calf does not care seriously. Mali, a servant, comes to Prema Gowda and tells:

Oh, oh, oh. Poor Gauri. Having male-calf. If he were a female, he will be worshipped, like his mother. But now, he is useless. (CP-146)

Dattani also presents the nature of an opportunistic man. Devraj Gowda is a perfect man. He does everything according to his own requirement. He eats fresh and local vegetable. He has a cow for milk. He has a farm-house. But when his daughter chooses a local man to marry, he does not accept it and he is ready to give her daughter to a Gujarati boy who is totally different from his culture. As Devraj Gowda says: "All originally grown . We make our own manure. I don't trust the companies. (CP-148)

In a traditional society like India, parents think that they are doing everything for their children but they do not give proper opportunities to a child so as to grow and develop. Prema and Devraj Gowda do their best for their daughter but they ignore the most important thing regarding marriage. Even Chandrakant Patel and Kusumben Patel do not care about the likes and dislikes of their children in the matter of marriage. But the new generation is very frank. They share their feelings and emotions openly. They also talk frankly and freely. Lata wants 
to run away to know the decision of her parents but Mali prevents her from doing so. After their mutual agreement, both Alpesh and Lata take the decision. The marriage ceremony takes place according to the Carnatic wedding system. Both families are happy. They enjoy that they have chosen the right person for their children. They exchange their greetings in the very jolly mood but till last the families do not know the hidden agreement between Alpesh and Lata. After marriage, they are very happy because they know each other and they also know that no one will interfere in other's work. The last scene of the play is very interesting and remarkable:

Lata: Where do we meet up?

Alpesh: You've got my cell-phone number, haven't you? Give me a call when you're through.

Lata: What do we tell Baa?

Alpesh: You'll do the shopping, right? (CP-158)

Thus these two characters do the needful. They have a mutual business; they respect each other's business. They very easily, search the way to deceive their parents. This play very beautifully shows the thoughts and views of a gay man like Alpesh who can ignore his wife Lata for his partner Trilok. Lata is now, no doubt, the wife of Alpesh but still, Salim reigns over her heart and mind. Therefor, this play actually mocks at the Indian wedding system which writes the script to do the needful but through mutual understanding.

The pay 'Do the Needful' is concerned with the theme of Indian marriage system but it has a universal effect. Alpesh is a gay guy and is forced to marry. He has no option but opts for making through an internal arrangement. Therefor it is the modern drama containing almost all the features of a modern man and modern feelings. It has almost all the features of a modern psychological novel diving deep into the psyche of the character which is often hidden beneath the surface. Influenced by the concept of Sigmund Freud about the various 
layers of mind this play also goes deeper and deeper in the minds of almost all the characters who are different in their outward and inward visions. What they behave outwardly is seldom present in their inward life. So far as the technique and style are concerned Mahesh Dattani has laid a new stone in the great mansion of modern play with the help of his beautiful images and symbols, plot-construction, unconventional theme and above all a new stagesetting. 


\section{References}

www.penguin.co.in

Dattani, Mahesh.Collected Plays, New Delhi, Penguin Book India Ltd, 2000. 